An Introduction to

Cancer Medicine 


\title{
AN INTRODUCTION TO CANCER MEDICINE
}

\author{
KENNETH C. CALMAN, M.D., Ph.D. \\ Cancer Research Campaign \\ Professor of Clinical Oncology, The University of Glasgow, Scotland \\ and \\ JOHN PAUL, M.B., Ch.B., Ph.D., F.R.S.E. \\ Director, Beatson Institute for Cancer Research, Glasgow, Scotland
}

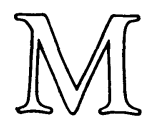


(C) Kenneth C. Calman and John Paul 1978

Softcover reprint of the hardcover 1st edition 1978 978-0-333-21277-6

All rights reserved. No part of this publication may be reproduced or transmitted, in any form or by any means, without permission

First published 1978 by

THE MACMILLAN PRESS LTD

London and Basingstoke

Associated companies in Delhi Dublin

Hong Kong Johannesburg Lagos Melbourne

New York Singapore and Tokyo

\section{British Library Cataloguing-in Publication Data}

Calman, Kenneth Charles

An introduction to cancer medicine.

1. Cancer

I. Title II. Paul, John, b. 1922

616.9'94 RC261

ISBN 978-0-333-21278-3 ISBN 978-1-349-15977-2 (eBook)

DOI 10.1007/978-1-349-15977-2

This book is sold subject to the standard conditions of the Net Book Agreement

The paperback edition of this book is sold subject to the condition that it shall not, by way of trade or otherwise, be lent, resold, hired out, or otherwise circulated without the publisher's prior consent in any form of binding or cover other than that in which it is published and without a similar condition including this condition being imposed on the subsequent purchaser 


\section{Contents}

Preface

1 Introduction

Part 1: Basic aspects of cancer

2 The cancer cell

3 Prevalence of cancer - epidemiology 29

4 Physical and chemical causes $\quad 40$

5 Tumour viruses $\quad 50$

6 Genetic factors $\quad 60$

7 Immunological and endocrine factors 66

8 General pathology $\quad 77$

Part 2: The clinical approach to the patient with cancer

9 The approach to the patient 85

10 Diseases associated with cancer $\quad 93$

11 The management of cancer 100

Part 3: The treatment of cancer

12 The surgical treatment of cancer 105

13 Radiotherapy 111

14 Cancer chemotherapy 123

15 Hormone therapy in cancer 138

16 Immunotherapy 143

17 Other methods of treating cancer 148

18 The multimodality approach to cancer therapy 151

19 Cancer in children 157

20 The results of cancer treatment 160

Part 4: The cancer patient and the community

21 The cancer care team 165

22 Epidemiology and the prevention of cancer 169

23 Early diagnosis and screening in cancer management 171

24 Public education on cancer 177

25 Terminal care and pain control 182

26 The logistics of cancer care 193

Appendix: Help agencies in cancer care in the United Kingdom 195

Bibliography 196

Index 


\section{Preface}

This book has grown out of a number of discussions between clinicians and scientists in an attempt to define the place of cancer medicine in the undergraduate medical course. It is also a reflexion of a new attitude to the approach to cancer involving the integration, not only of the basic and clinical aspects of the subject, but also of the many clinical disciplines involved in cancer care. It is intended, therefore, as an introduction to the subject for medical students.

However, it is clear that many other professional groups including nurses, social workers and other ancillary workers, together with basic scientists, might welcome such a volume. For this reason some of the sections of the book have been adjusted to meet this need.

During the preparation of this book, many colleages have been consulted, and we gratefully acknowledge their help and advice. We are indebted for secretarial help to Mrs M. McLeod, Miss E. Dickson, Mrs M. Downie and Mrs J. Peffer, and for artwork to Mr Donald and Mr Ellis. Finally we should like to express our thanks to Mr Charles Fry and the staff of The Macmillan Press for their help in producing this book.

Glasgow, 1977 